\title{
COVID-19 Anxiety Disorder among Tabuk University Students
}

\author{
Dr. Ehab Ahmed Frah
}

University of Tabuk, Faculty of Science, Department of Statistics, Tabuk, Saudia Arabia.

*Corresponding Author: Dr. Ehab Ahmed Frah, University of Tabuk, Faculty of Science, Department of Statistics, Tabuk, Saudia Arabia.

\begin{abstract}
During times of pandemic, people are prone to stress- or anxiety-related responses that include fear of becoming diseased, horror of coming into contact with possibly contaminated objects or surfaces, panic of foreigners who might be carrying the fear of the symptomatic consequences of the pandemic, and obsessivecompulsive behaviors. This study reports on findings on the epidemiology of generalized anxiety disorder among students at Tabuk University, Saudi Arabia. The researcher developed and adopted a 25-item Anxiety Disorder and Panic of Coronavirus Scale based on the Composite International Diagnostic Interview (CIDI) 3.0 (to assess DSM-IV disorders) and the Acute Panic Disorder Inventory to measure the anxiety and panic levels related to COVID-19. Participants comprised a random sample of 1512 students from all faculties during April 2020. The researcher used descriptive statistics including frequency and percentage data to describe responses, and the mean and standard deviation of scores for classification of levels of panic and anxiety disorder. T-test was used to test the significant difference of panic and anxiety disorder level to characteristics variables, with $p \leq 0.05$ value being considered statistically significant. The study finds that $73 \%$ of Tabuk university students have anxiety disorder and panic due to coronavirus at varying levels, from occasionally to all of the time, and the anxiety disorder and panic is affected by student age and academic level.
\end{abstract}

Keywords: COVID-19anxiety, students, panic, $t$-test

\section{INTRODUCTION}

\section{Anxiety}

Anxiety is a natural reaction in some situations to perceived threats and tension, and it can be a positive adaptation in galvanizing efforts to overcome challenges and being attentive to dangerous situations. However, when experienced for a prolonged period or due to irrational perceptions, anxiety can be a crippling disorder. Anxiety ranges from normal anxiousness to excessive fear or anxiety. Anxiety disorders have high prevalence, affecting $30 \%$ of adults with mental disorders at some pointin their lives. On the other hand, anxiety disorders are treatable with many several available and effective treatments. Treatment aids most people to manage and control their normal and productive lives. Anxiety is defined as the expectation of future fear and related to muscle tension and avoiding behavior. Anxiety disorders can affect people as try to avoid situations that generate or exacerbate their symptoms. They have a direct negative effect on people's life satisfaction, reflected in negative experiences and outcomes in academic achievement, job performance, and personal relationships. There are various types of common anxiety disorders, including generalized anxiety disorder, panic disorder, specific phobias, agoraphobia, social anxiety disorder, and separation anxiety disorder[1]. Panic disorder is the most pertinent to the current study.

\section{Panic Disorder}

The fundamental symptom of panic disorder is frequent panic attacks, a crushing mixture of bodily and psychosomatic distress. During an attack, some of the following symptoms may occur in various combinations [1]:

- Palpitations, rapid heart rate

- Sweating

- Trembling or shaky

- Shortness of breath feeling or smothering sensations

- Chest pain

- Feeling dizzy, light-headed, or faint

- A choking feeling

- Numbness or tingling

- Chills 
- Vomiting or abdominal pains

- Detached feeling

- losing control fear

- Dying fear

Due to the severity of symptoms, some panic attack experiences maybe considered as heart attacks by their sufferers, and indeed panic disorder (as opposed to individual attacks) is associated with new onset coronary heart disease, acute myocardial infarction, and cardiac mortality, particularly among younger patients [2], as well as chronic obstructive pulmonary disease[3]. Panic attacks may be predictable, such as a reaction to a feared object, or unexpected, and they can actually occur for no reason. The most common age is 22-23 for the onset of panic disorder. Panic attacks may arise with other mental disorders, such as depression or PTSD [1].

\section{COVID-19 Impacts}

The novel coronavirus COVID-19 (SARS-CoV2 ) is very infectious, but most patients do not experience severe symptoms, and can recover without hospitalization. Higher risk of serious complications is generally only among older adults and patients with 'severe underlying medical conditions like heart or lung disease or diabetes' [4].The virus that causes COVID-19 is transmitted through droplets of an infected person who coughs, sneezes, or exhales; droplets are disseminated to floors and surfaces where they can be transmitted. Infection can occur by breathing in close proximity of someone who has COVID-19, or touching eyes, nose or mouth directly after touch a contaminated surface.

The global community has faced unprecedented challenge in dealing with the COVID-19 pandemic, bringing governments, international organizations, and private sector industries together in collaborative efforts to reduce transmission and develop treatment. Nevertheless, public fear of the virus itself and associated responses (e.g. social distancing measures associated with "lockdown" policies in most countries) has caused widespread panic, anxiety, and stress. The Centers for Disease Control and Prevention [4] notes that anxiety and tension during an infectious disease outbreak may include:

- Worry about personal health and the health of your loved ones
- Disrupted patterns of sleeping or eating

- Difficulty sleeping or concentrating

- Exacerbation of chronic health problems

- Negative mental health conditions and disorders

- Increased consumption of alcohol, tobacco, or other recreational drugs

The purpose of this study is to determine the prevalence of anxiety related to corona virus amount among students at the University of Tabuk and to assess their perceptions of related risks according to socio-demographic characteristics.

\section{MATERIAL AND METHODS}

\section{Study Design and Sampling Size}

This analytical cross-sectional study was conducted among1512 randomly selected Tabuk University students from all faculties who voluntarily agreed to complete the study questionnaire, disseminated via their university email accounts during April 2020.The larger the target sample size, the higher the external validity and the greater the generalizability of the study. This study aimed to maximize reach and gather data from as many respondents as possible. The representative target sample size needed, to achieve the study objectives and sufficient statistical power, was calculated with a sample size calculator. The sample size calculator arrived at 1,035 participants, using a margin of error of $\pm 3 \%$, a confidence level of $95 \%$, design effect 1.4 , a $50 \%$ response distribution, and 34,246 students.

\section{Measurement Tool and Data Analysis}

The researcher developed a 25-item Anxiety Disorder and Panic of Coronavirus Scale incorporating the fully structured Composite International Diagnostic Interview (CIDI) 3.0 to assess DSM-IV disorders [5]. The Acute Panic Disorder Inventory questionnaire was used to ask participants the extent to which they have experienced panic-like symptoms, which they rank using a five-point Likert scale: never(0), occasionally(1), half of the time(2), most of the time(3), and all of the time(4). The total score can range from 0 to 100 , with higher scores indicating greater severity of panic and anxiety disorder. Internal consistency of the measures was tested using a reliability test where the Cronbach alpha coefficient aided in determining the reliability of the variables. 


\section{Statistical Analysis}

The statistical analysis was performed using the SPSS 22.0 package for Windows. The overall scores were totaled from answers to the specific items of the questionnaires. Descriptive statistics were utilized, including frequency and percentage, to describe responses, and the mean and standard deviation of scores indicated levels of panic and anxiety disorder. T-test was used to identify significant differences between panic and anxiety disorder and participant variables (age, sex, faculty, and study level). According to the questionnaire answers, statistical significance was determined at $\mathrm{p} \leq 0.05$ value.

The larger the target sample size, the higher the external validity and the greater the generalizability of the study. This study aimed to maximize reach and gather data from as many respondents as possible. The representative target sample size needed, to achieve the study objectives and sufficient statistical power, was calculated with a sample size calculator. 1,035 participants, using a margin of error of $\pm 3 \%$, a confidence level of $95 \%$, design effect 1.4 , a $50 \%$ response distribution, and 34,246 students.

\section{RESULTS}

The majority of participants $(74 \%)$ were aged 19-22 years, with slightly more females $(56 \%)$ than males $(44 \%)$. They were studying in the faculties of science (Sciences, Engineering, and Computer Sciences), medicine (Medicine, Pharmacy, and Applied Medical Sciences), and humanities and theoretical studies (Education and Arts, Sharia and Laws, and Business Administration). The majority were multi-level undergraduate students (at different years of their study programs), with a representative cohort of postgraduate students. Table 1 shows the demographic characteristics of participations, and Table 2 shows participant responses to the survey, with mean and standard deviation (SD) values. Internal consistency of the measures was tested using a reliability test where the Cronbach alpha coefficient aided in determining the reliability of the variables. The results showed that the Cronbach alpha was 0.65. the range of Cronbach alpha within 0.6 to 07 is considered adequate and reliable. It is attested that the items used to measure Anxiety Disorder and Panic of COVID-19 are therefore acceptable.

Table1. Sample distribution characteristics

\begin{tabular}{|c|c|c|}
\hline & Frequency & Percent \\
\hline \multicolumn{3}{|l|}{ Age } \\
\hline $15-18$ years & 54 & 3.6 \\
\hline $19-22$ years & 1120 & 74.1 \\
\hline $23+$ years & 338 & 22.4 \\
\hline Total & 1512 & 100.0 \\
\hline \multicolumn{3}{|c|}{ Sex of student } \\
\hline Female & 846 & 56.0 \\
\hline Male & 666 & 44.0 \\
\hline Total & 1512 & 100.0 \\
\hline \multicolumn{3}{|l|}{ Faculty } \\
\hline Science & 994 & 65.7 \\
\hline Medical & 172 & 11.4 \\
\hline Theory & 346 & 22.9 \\
\hline Total & 1512 & 100.0 \\
\hline \multicolumn{3}{|c|}{ Study level (year) } \\
\hline 1 & 180 & 11.9 \\
\hline 2 & 420 & 27.8 \\
\hline 3 & 342 & 22.6 \\
\hline 4 & 374 & 24.7 \\
\hline 5 & 44 & 2.9 \\
\hline 6 & 84 & 5.6 \\
\hline Postgraduate & 68 & 4.5 \\
\hline Total & 1512 & 100.0 \\
\hline
\end{tabular}

Table 2. Participant responses to all items

\begin{tabular}{|l|c|c|c|}
\hline Items & Mean & SD & Result \\
\hline I am afraid of being infected with novel corona virus & 1.78 & 1.2 & Half of the time \\
\hline $\begin{array}{l}\text { I am obsessed with the idea that I will be infected with the corona } \\
\text { virus }\end{array}$ & 1.31 & 1.2 & Occasionally \\
\hline
\end{tabular}




\begin{tabular}{|c|c|c|c|}
\hline $\begin{array}{l}\text { I sweat all over when I know of an infection in Tabuk or anywhere } \\
\text { around me }\end{array}$ & 1.06 & 1.2 & Occasionally \\
\hline $\begin{array}{l}\text { I am worried about my health due to the spread of the novel corona } \\
\text { virus }\end{array}$ & 2.06 & 1.3 & Half of the time \\
\hline $\begin{array}{l}\text { I think the issue is simple and there is no need for global panic } \\
\text { regarding the novel corona virus }\end{array}$ & 1.23 & 1.2 & Occasionally \\
\hline $\begin{array}{l}\text { I feel the chills in my body from the global reports on the status of the } \\
\text { novel corona virus }\end{array}$ & 1.87 & 1.3 & Half of the time \\
\hline $\begin{array}{l}\text { I believe that my physical immunity is strong enough to resist } \\
\text { infection of the novel corona virus }\end{array}$ & 1.86 & 1.2 & Half of the time \\
\hline My heart beats when I know of a new case of corona virus & 1.11 & 1.3 & Occasionally \\
\hline $\begin{array}{l}\text { I worry about my health once someone sneezes around me because of } \\
\text { corona virus }\end{array}$ & 1.55 & 1.3 & Occasionally \\
\hline $\begin{array}{l}\text { I ignore anyone who underestimates the risk of infection of the corona } \\
\text { virus }\end{array}$ & 1.74 & 1.4 & Half of the time \\
\hline I overuse sanitizers to disinfect my hands from bacteria and germs & 1.52 & 1.3 & Occasionally \\
\hline Talking about corona virus makes me feel nauseous & 1.27 & 1.4 & Occasionally \\
\hline $\begin{array}{l}\text { I have been nervous and anxious about my family since I first knew of } \\
\text { the spread of corona virus }\end{array}$ & 2.67 & 1.4 & Most of the time \\
\hline $\begin{array}{l}\text { I almost cannot sleep as a result of excessive thinking about the } \\
\text { possibility of catching corona virus }\end{array}$ & 0.55 & 1.1 & Never \\
\hline $\begin{array}{l}\text { I exaggerate in my adherence to medical instructions and guidelines } \\
\text { for protection against corona virus }\end{array}$ & 1.41 & 1.4 & Occasionally \\
\hline I tremble with the fear of infection with corona virus & 0.74 & 1.2 & Never \\
\hline Too much talk about corona virus in the media annoys me deeply & 1.96 & 1.5 & Half of the time \\
\hline $\begin{array}{l}\text { My imagination does not stop seeing scenes of people infected with } \\
\text { corona virus }\end{array}$ & 0.89 & 1.3 & Occasionally \\
\hline $\begin{array}{l}\text { My imagination does not stop seeing scenes of people infected with } \\
\text { corona virus }\end{array}$ & 0.81 & 1.2 & Occasionally \\
\hline I am horrified if I get a regular cold, for fear of corona virus & 1.18 & 1.4 & Occasionally \\
\hline $\begin{array}{l}\text { It captures my thinking that the end of the world is near due to the } \\
\text { spread of corona virus }\end{array}$ & 1.21 & 1.4 & Occasionally \\
\hline I exaggerate in using protective mask and gloves in public places & 1.33 & 1.4 & Occasionally \\
\hline $\begin{array}{l}\text { I feel a headache when I receive some news about new cases of } \\
\text { corona virus in Tabuk }\end{array}$ & 1.08 & 1.4 & Occasionally \\
\hline It makes me upset to hear something about the corona virus & 1.69 & 1.4 & Half the time \\
\hline I have become more afraid of death & 1.02 & 1.3 & Occasionally \\
\hline Total & 1.40 & 0.8 & Occasionally \\
\hline
\end{tabular}

The average results of the questionnaire items indicated that the distribution of the anxiety disorder and panic levels experienced by students were as follows: occasionally $(65.7 \%)$, half of the time $(23.1 \%)$, and most of the time $(3.8 \%)$; and only $(7.7 \%)$ as never among the student.

The results for the classification of the study population according to the frequency with which they suffer from high anxiety and panic from COVID-19, using the five-point Likert scale, are shown in Figure 1 and Table 3. It can be seen that only $4 \%$ of Tabuk University students suffered from high anxiety and panic from COVID-19 all of the time, while 9\% did most of the time. Students who occasionally had high anxiety and panic from COVID-19 represented the largest proportion $(41 \%)$, while $20 \%$ reported half of the time. We can conclude that $74 \%$ of Tabuk university students experienced anxiety disorder and panic due to coronavirus at different levels, from occasionally to all of the time.

Table3. Summary of participant responses

\begin{tabular}{|l|c|c|}
\hline Response & Frequency & Percentage \\
\hline Never & 406 & $27 \%$ \\
\hline Occasionally & 614 & $41 \%$ \\
\hline Half of the time & 300 & $20 \%$ \\
\hline Most of the time & 138 & $9 \%$ \\
\hline All of the time & 54 & $4 \%$ \\
\hline Total & $\mathbf{1 5 1 2}$ & $\mathbf{1 0 0 \%}$ \\
\hline
\end{tabular}




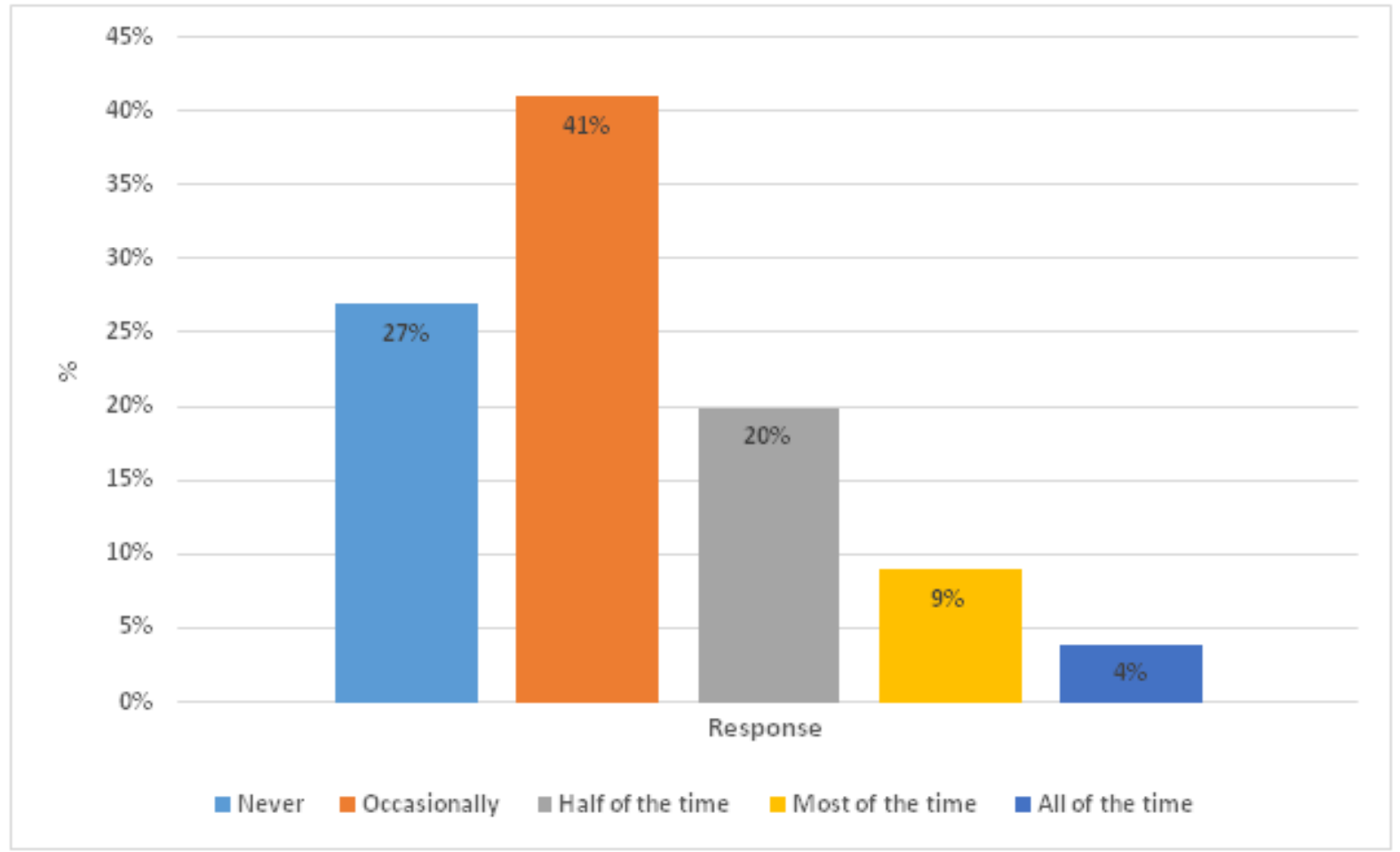

Figure1. Summary of participant responses

In order to find out whether there is a significant difference in panic and anxiety disorder in relation to characteristics variables, T-test was used for an independent sample. T-test or oneway analysis of variance (ANOVA) were used to Table4. T-test results determine any significant difference of anxiety disorder or panic level among students of Tabuk University in general, and regarding the variables study level, age group, sex, and faculty. Results are shown in Table 4.

\begin{tabular}{|c|c|c|c|c|}
\hline & $\mathbf{N}$ & Mean & SD & P-value \\
\hline \multicolumn{5}{|l|}{ Sex } \\
\hline Female & 846 & 1.39 & 0.79 & \multirow{2}{*}{0.6} \\
\hline Male & 666 & 1.41 & 0.82 & \\
\hline \multicolumn{5}{|c|}{ Study level (year) } \\
\hline 1 & 180 & 1.57 & 0.99 & \multirow{7}{*}{0.000} \\
\hline 2 & 420 & 1.40 & 0.78 & \\
\hline 3 & 342 & 1.34 & 0.79 & \\
\hline 4 & 374 & 1.35 & 0.69 & \\
\hline 5 & 44 & 1.38 & 0.96 & \\
\hline 6 & 84 & 1.68 & 0.86 & \\
\hline Postgraduate & 68 & 1.13 & 0.71 & \\
\hline \multicolumn{5}{|l|}{ Faculty } \\
\hline Science & 994 & 1.38 & 0.79 & \multirow{3}{*}{0.435} \\
\hline Medical & 172 & 1.42 & 0.82 & \\
\hline Theory & 346 & 1.44 & 0.85 & \\
\hline \multicolumn{5}{|l|}{ Age } \\
\hline $15-18$ years & 54 & 1.69 & 1.27 & \multirow{3}{*}{0.024} \\
\hline 19 - 22 years & 1120 & 1.39 & 0.76 & \\
\hline $23+$ years & 338 & 1.37 & 0.84 & \\
\hline
\end{tabular}

\section{DISCUSSION}

The aim of the present study is to examine the prevalence of anxiety disorder and panic among Tabuk University students, and to relate this to particular variable characteristics, using a random sample that was representative according to sex, age, faculty, and study level, enabling accurate results to be achieved concerning anxiety disorder and panic related to COVID19.The study found that about $17(65.4 \%)$ items of the questionnaire's final average score were answered with occasionally, indicating that the majority of students sometimes have anxiety about COVID-19 infection. This is perhaps 
related to the direct impacts of the public policy response to the crisis, with Saudi universities delivering classes via online teaching and distance learning under lockdown conditions. Almost a quarter of items were answered with half of the time $(\mathrm{n}=6,23.1 \%)$, but only one item with most of the time.

The combined results for those experiencing anxiety related to COVID-19 most of the time (n $=138,9 \%)$, and all of the time $(\mathrm{n}=54,4 \%)$ indicates that $13 \%$ of participants experienced prolonged and pervasive levels of distress. While this can be expected given the intense fear among governments and many scientific institutions confronted with the exponential spread of the virus worldwide in April 2020, when the fieldwork was conducted. At that point the outbreak had been reported in over 213 countries, with projections indicating that millions of people could be killed, with few known effective treatments or a vaccine, and media reporting and government policy relating to this scenario doubtlessly fed into the anxiety experienced by students. Nevertheless, it must be borne in mind that over a quarter of participants $(\mathrm{n}=406,27 \%)$ reported that they never experienced anxiety related to COVID-19.

Statistically significant differences were detected among participants related to their study level between the first and third years (0.032) and postgraduates (0.002). Third year students had significant differences only with those in their sixth year (0.010), and fourth-year participants also had such differences with those in their sixth year (0.017). The sixth year also had a significant difference with postgraduates (0.001). That means there is significant variation in anxiety disorder and panic related to COVID-19 among the students of Tabuk University related to study level, especially regarding responses of occasionally and half of the time.

The results indicate statistically significant differences according to student age group for occasionally and half of the time responses, including between the cohorts aged 15-18 and $19-22$ years $(0.022)$; and $15-18$ and over 23 years (0.023).

These results are compatible with findings from China showing that more than $25 \%$ of the population experienced moderate to severe levels of stress- or anxiety-related symptoms in response to COVID-19[6,7]. These levels are similar to those reported during the SARS outbreak [8].

\section{Conclusion}

To our knowledge, this is the first study to assess, describe, and evaluate the anxiety disorder and panic arising from coronavirus among Tabuk University students, and it is among the pioneering studies of the subject of student anxiety in Saudi Arabia in general. The results indicate that aside from $27 \%(\mathrm{n}=406)$ who reported never experiencing anxiety in relation to COVID-19, of the $73 \%$ of the study population who experienced some form of anxiety disorder, $41 \%$ did so occasionally $(\mathrm{n}=$ $614), 20 \%$ half of the time $(\mathrm{n}=300), 9 \%$ most of the time $(\mathrm{n}=138)$, and $4 \%$ all of the time $(\mathrm{n}=$ 54). These findings add to our understanding of how public health crises such as pandemics have major psycho-social health impacts on student populations, backing policymakers to commit more resources to raising awareness and health education among such groups, with the implication of allocating specialist therapy and mental health support for those requiring it.

\section{ACKNOWLEDGEMENT}

This was supported on part by the Sensor Networks and Cellular Systems (SNCS) Research Center at the University of Tabuk, Tabuk, Saudia Arabia.

\section{REFERENCES}

[1] Parekh, R. What are anxiety disorders? American Psychiatric Association. Physician review. Available from:https://www. psychiatry. org/patients-families/anxiety-disorders/what-areanxiety-disorders\#: :text=Anxiety \%20is \%20a $\% 20$ normal\%20reaction,involve $\% 20$ excessive $\%$ 20fear\%20or\%20anxiety [Accessed $1^{\text {st }}$ October 2020].

[2] Walters K, Rait G, Petersen I, Williams R, Nazareth I. Panic disorder and risk of new onset coronary heart disease, acute myocardial infarction, and cardiac mortality: cohort study using the general practice research database. European Heart Journal. 2008;29(24):29812988. Available from: doi:10.1093/ eurheartj/ ehn477.

[3] Livermore N, Sharpe L, McKenzie D. Panic attacks and panic disorder in chronic obstructive pulmonary disease: a cognitive behavioral perspective. Respiratory Medicine. 2010;104 (9):1246-1253. Available from: doi:10.1016/ j.rmed.2010.04.011.

[4] Centers for Disease Control and Prevention. Coronavirus Disease 2019 (COVID-19). Available at: https://www.cdc.gov/ corona virus/2019-ncov/daily-life-coping/managingstress-anxiety.html [Accessed $1^{\text {st }}$ October 2020]. 
COVID-19 Anxiety Disorder among Tabuk University Students

[5] Kessler RC, Üstun TB (2004). The World Mental Health (WHM) Survey Initiative Version of the World Health Organization (WHO) Composite International Diagnostic Interview (CIDI). International Journal of Methods in Psychiatric Research. 2004; 13: 93-121.

[6] Qiu J, Shen B, Zhao M, Wang Z, Xie B, Xu Y. A nationwide survey of psychological distress among Chinese people in the COVID-19 epidemic: implications and policy recommendations. General Psychiatry. 2020; 33:e100213. Available from: doi:10.1136/ gpsych-2020-100213.
[7] Wang C, Pan R, Wan X, Tan Y, Xu L, Ho CS, Ho RC. Immediate psychological responses and associated factors during the initial stage of the 2019 coronavirus disease (COVID-19) epidemic among the general population in China. International Journal of Environmental Research and Public Health. 2020;17(5):1729. Available from: doi:10.3390/ijerph17051729.

[8] Cheng SK, Wong CW, Tsang J, Wong KC. Psychological distress and negative appraisals in survivors of severe acute respiratory syndrome (SARS). Psychological Medicine. 2004;34 (7):1187-1195. Available from: doi:10. 1017 /s0033291704002272. PMID: 15697045.

Citation: Dr. Ehab Ahmed Frah, "COVID-19 Anxiety Disorder among Tabuk University Students", International Journal of Research Studies in Medical and Health Sciences. 2020; 5(12): 1-7.

Copyright: (C) 2020 Dr. Ehab Ahmed Frah, This is an open-access article distributed under the terms of the Creative Commons Attribution License, which permits unrestricted use, distribution, and reproduction in any medium, provided the original author and source are credited. 